\title{
ANTI-INFLAMMATORY ACTIVITY OF KNEMA ATTENUATA (HOOK. F. AND THOMSON) WARB ETHANOLIC STEM BARK EXTRACT IN ALBINO WISTAR RATS
}

\author{
SUPRIYA RAJA H* \\ Department of Pharmacology, College of Pharmaceutical Sciences, Government Medical College, Trivandrum, Kerala, India. \\ Email: sraja968@gmail.com
}

Received: 27 October 2018, Revised and Accepted: 16 March 2019

\section{ABSTRACT}

Objective: Knema attenuata (Myristicaceae), popularly known as "wild nutmeg," is an endemic tree species from Western Ghats, which has been used in folk medicine. Conventionally, the stem bark of K. attenuata is used for treating inflammatory conditions without any scientific information available for the same. The present study was undertaken to evaluate the anti-inflammatory activity of the ethanolic stem bark extract (ESBE) of K. attenuata using in vivo and in vitro screening models.

Methods: The ethanolic extract of stem bark was prepared by soxhlation, and its cytotoxicity in RAW 264.7 cell line was assessed using MTT assay method. In vivo anti-inflammatory effect of extract was estimated in rats using carrageenan-induced paw edema model and cotton pellet-induced granuloma model. The in vitro anti-inflammatory activity of the extract was evaluated by cyclooxygenase and lipoxygenase inhibition assay, estimation of myeloperoxidase activity, and determination of cellular nitrite levels in lipopolysaccharide-stimulated RAW 264.7 macrophage cells.

Results: Toxic symptoms were not observed for the ESBE. The extract demonstrated significant anti-inflammatory activity in both in vivo and in vitro models. The anti-inflammatory action exhibited by the extract was a result of the inhibition of leukocyte migration and nitric oxide pathway and partially by inhibition of mediators such as prostaglandins and leukotrienes.

Conclusion: Findings from the study provide the evidence for the popular use of stem bark extract of $K$. attenuata as a potential anti-inflammatory agent.

Keywords: Knema attenuata, Folk use, anti-inflammatory activity, Carrageenan-induced paw edema.

(C) 2019 The Authors. Published by Innovare Academic Sciences Pvt Ltd. This is an open access article under the CC BY license (http://creativecommons. org/licenses/by/4. 0/) DOI: http://dx.doi.org/10.22159/ajpcr.2019.v12i4.30500

\section{INTRODUCTION}

Inflammation is a protective biological response of body toward tissue injury or infection. Inflammatory mediators such as prostaglandins, histamine, lysosomal enzymes, leukotrienes, bradykinin, and cytokines amplify the inflammatory response to remove the harmful stimuli [1]. Inflammatory response can be either acute or chronic. Acute inflammation is the initial response to eliminate the causative agent, and when it fails to resolve, chronic inflammation is established [2,3]. Chronic inflammation, associated with increased free radical production, is involved in the pathogenesis of various diseases such as diabetes, lipid dysregulation, arthritis, and cardiac disorders $[4,5]$. Nowadays, the usage of synthetic drugs dominates the medicinal market for treating inflammatory conditions. However, their prolonged administration may provoke adverse effects such as gastric irritation and cardiac complications [6,7]. This initiates the need for searching an efficient and safe complimentary medicine. The bioactive compounds isolated from medicinal plants that exhibit potent antiinflammatory activity can be one of the reliable sources that serve the purpose [8].

Knema attenuate (Myristicaceae), commonly known as "wild nutmeg," is an endemic tree species native to southern India extending from Konkan southward of Maharashtra, Goa, Karnataka, Tamil Nadu, and Kerala [9]. This species has been used in folk medicine as an ingredient of ayurvedic "Ashwagandhadi nei," for the treatment of conditions such as spleen disorders, breathing disorders, and impaired taste sensation. The stem bark is also being used in the form of decoction for the treatment of jaundice and chronic fever [10]. Studies on the stem bark of $K$. attenuata reported the presence of a lignan attenuol; closely related to lignans isolated from the plants of Myristicaceae family [11]. Lignans are a large group of compounds, which exhibit antioxidant, liver protection, anti-inflammatory, and anticancerous properties [12]. In addition, the presence of a common constituent anacardic acid has been reported in plants under genus Knema, which possesses antibacterial, anticancer, and anti-inflammatory properties [13]. However, scientific data on the pharmacological screening in the stem bark of $K$. attenuata are not available till date. Therefore, the present study was designed to evaluate the anti-inflammatory potential of ethanolic stem bark of $K$. attenuata using both in vivo and in vitro screening techniques.

\section{MATERIALS AND METHODS}

\section{Plant material and extract preparation}

The stem bark of K. attenuata for the proposed study was collected from Kerala Forest Research Institute, Peechi and Thrissur in the month of January 2015. The plant material was taxonomically identified and authenticated by Dr. VB Sreekumar, Scientist (Botany Department), Kerala Forest Research Institute, Peechi, Thrissur. The fresh stem bark was thoroughly washed, spread in trays, and air dried for 3 weeks. The dried stem bark was then powdered and sieved (sieve no: 44) for extraction.

The stem bark powder of $K$. attenuata $(50 \mathrm{~g})$ was packed in a thimble and loaded in a Soxhlet apparatus. After defatting stem bark powder with petroleum ether $\left(60-80^{\circ} \mathrm{C}\right)$, it was subjected to continuous extraction with $300 \mathrm{ml}$ of $95 \%$ ethanol. Excess solvent was recovered by vacuum evaporation (at $40^{\circ} \mathrm{C}$ ) to obtain the dried ethanolic stem bark extract (ESBE) with a percentage yield of $17.8 \% \mathrm{w} / \mathrm{w}$ [14]. 


\section{Animals}

Wistar rats of either sex (150-250 g) procured from animal house (Reg. No: 752/02/a/CPCSEA) of Government Medical College, Trivandrum, were used for the studies. The animals were housed in propylene cages (three per cage) with dust-free husk as bedding material under standard condition of temperature $\left(25 \pm 2^{\circ} \mathrm{C}\right)$ and relative humidity (30-70\%) with a 12:12 light-dark cycle and fed with standard rodent pellet and water except during experimentation. Institutional Animal Ethics Committee, Government Medical College, Thiruvananthapuram, approved the experimental protocols on 17/12/2014 (Approval no: 03/13/2014/MCT).

\section{Cell culture}

RAW 264.7 macrophage cells were cultured in DMEM, supplemented with $10 \%$ heat-inactivated fetal bovine serum, antibiotics (penicillin and streptomycin; $100 \mu \mathrm{g} / \mathrm{ml}$ each), and $1.5 \%$ sodium bicarbonate. The cell lines were maintained under a temperature of $37^{\circ} \mathrm{C}$ in a humidified atmosphere of $5 \% \mathrm{CO}_{2}[15]$.

\section{Cell viability assay}

RAW 264.7 cells at a density $\times 210^{4}$ cells/well were seeded on a 96-well microplate containing media. After overnight incubation, the media from each well were removed, and fresh media were placed with or without ESBE at concentration range of $6.25-100 \mu \mathrm{g} / \mathrm{ml}$. After $24 \mathrm{~h}$ of incubation, the media were replaced, and MTT $(50 \mu \mathrm{l})$ was added to cells, which were then incubated for $4 \mathrm{~h}$ at $37^{\circ} \mathrm{C}$. The media were removed, and the MTT-formazan crystals were solubilized in dimethyl sulfoxide. Absorbance was recorded at $570 \mathrm{~nm}$, and $\mathrm{IC}_{50}$ was calculated [16].

\section{In vivo pharmacological studies}

\section{Anti-inflammatory assays}

Grouping of animals

Wistar rats of either sex (150-250 g) were randomly divided into four groups with each groups consisting of six animals.

Animals of Group 1 (control) received water, animals of Group 2 received standard drug (carrageenan-induced paw edema: Indomethacin $10 \mathrm{mg} / \mathrm{kg}$; cotton pellet-induced granuloma: Dexamethasone $10 \mathrm{mg} / \mathrm{kg}$ ), animals of Group 3 received ESBE $250 \mathrm{mg} / \mathrm{kg}$, and animals of Group 4 received ESBE $500 \mathrm{mg} / \mathrm{kg}$ orally.

\section{Carrageenan-induced paw edema in rat}

Edema was induced by injecting $0.05 \mathrm{ml}$ of $1 \%$ solution of carrageenan in $0.9 \%$ normal saline solution subcutaneously into the plantar region of left hind paw of each animal of all the groups. Their paw volumes were measured plethysmographically at $0,1,2,3$, and $4 \mathrm{~h}$ after carrageenan challenge. The percentage increase in paw volume was calculated. The difference of average values between treated animals and control group was calculated for each time interval and statistically analyzed.

Percentage inhibition of edema $=((C-D) / C)-100$

C - Percentage difference in paw volume of control group.

D - Percentage difference in paw volume of drug-treated group [17].

\section{Cotton pellet granuloma method}

Rats were anesthetized and their axillary skin was shaved and disinfected with $70 \%$ ethanol. Subcutaneous tunnel was created on the axilla region using a blunted forceps, and a sterilized cotton pellet weighing $50 \pm 1 \mathrm{mg}$ was implanted there, with the help of sterile instruments after which tunnels were stitched and closed. After $24 \mathrm{~h}$ of implantation, each animal group was treated orally with vehicle, standard or test drug continuously for 7 days. The animals were sacrificed, and the cotton pellets (along with granular tissue formed around) were removed on the $8^{\text {th }}$ day. The pellets were dried in an incubator at $60^{\circ} \mathrm{C}$ until they showed a stable weight. The percentage inhibition of granuloma formation was calculated using formula:
Percentage inhibition of dry weight of granuloma formation = $100[(\mathrm{~A}-\mathrm{B}) / \mathrm{A}]$

Where

$\mathrm{A}=$ Gain in dry weight of control pellets

$\mathrm{B}=$ Gain in dry weight of standard or test treated pellets [18].

\section{In vitro pharmacological studies}

Anti-inflammatory activity in cell lines

Raw 264.7 cells were grown to $60 \%$ confluence (log phase) followed by activation with lipopolysaccharide (LPS) $(1 \mu \mathrm{g} / \mathrm{ml})$. LPS-stimulated cells were exposed to different concentrations $(6.25 \mu \mathrm{g} / \mathrm{ml}, 12.5 \mu \mathrm{g} / \mathrm{ml}$, $25 \mu \mathrm{g} / \mathrm{ml}, 50 \mu \mathrm{g} / \mathrm{ml}$, and $100 \mu \mathrm{g} / \mathrm{ml}$ ) of ESBE and incubated for $24 \mathrm{~h}$. After incubation, cell lysate was prepared using which the anti-inflammatory assays were performed [19].

\section{Cyclooxygenase (COX) inhibitory assay}

The assay mixture contained Tris-HCl buffer, glutathione, hemoglobin, and enzyme contained in sample. The reaction was started by the addition of arachidonic acid and terminated after $20 \mathrm{~min}$ of incubation at $37^{\circ} \mathrm{C}$ by the addition of $0.2 \mathrm{ml}$ of $10 \%$ trichloroacetic acid in $1 \mathrm{~N} \mathrm{HCl}$, mixed, and $0.2 \mathrm{ml}$ of TBA was added, and contents were heated in a boiling water bath for $20 \mathrm{~min}$, cooled, and centrifuged at $1000 \mathrm{rpm}$ for $3 \mathrm{~min}$. The supernatant was measured at $632 \mathrm{~nm}$ for COX activity. The extent of inhibition was calculated using the following formula:

Percentage inhibition $=((\mathrm{C}-\mathrm{T}) / \mathrm{C}) \times 100$

$\mathrm{C}=$ Optical density of control; $\mathrm{T}=$ Optical density of test [20].

Lipoxygenase (LOX) inhibitory assay (assay of 5-lipoxygenase)

For this test, $70 \mathrm{mg}$ of linoleic acid and equal weight of tween 20 was dissolved in $4 \mathrm{ml}$ of oxygen-free water and mixed back and forth with a pipette avoiding air bubbles. Sufficient amount of $0.5 \mathrm{~N} \mathrm{NaOH}$ was added to yield a clear solution and then made up to $25 \mathrm{ml}$ using oxygen-free water. This was divided into $0.5 \mathrm{ml}$ portions and flushed with nitrogen gas before closing and kept frozen until needed. The reaction was carried out in a quartz cuvette at $25^{\circ} \mathrm{C}$ with $1 \mathrm{~cm}$ light path. The assay mixture contains $2.75 \mathrm{ml}$ tris buffer with a $\mathrm{pH}$ of 7.4, $0.2 \mathrm{ml}$ of sodium linoleate, and $50 \mu \mathrm{l}$ of the enzyme. The increase in optical density was measured in $234 \mathrm{~nm}$. The extent of inhibition was calculated using the formula:

Percentage inhibition $=((\mathrm{C}-\mathrm{T}) / \mathrm{C}) \times 100$

$\mathrm{C}=$ Optical density of control; $\mathrm{T}=$ Optical density of test [21].

Estimation of myeloperoxidase (MPO) enzyme activity

Cultured sample was mixed in a solution containing $50 \mathrm{mM} \mathrm{KH}_{2} \mathrm{PO}_{4} /$ $\mathrm{K}_{2} \mathrm{HPO}_{4}$ buffer ( $\mathrm{pH}$ 6) and $0.57 \mathrm{ml}$ hexadecyl trimethyl ammonium bromide. The samples were centrifuged at $2000 \mathrm{rpm}$ for $30 \mathrm{~min}$ at $4^{\circ} \mathrm{C}$, and resulting supernatant was assayed using a spectrophotometer for MPO. Sample was mixed with $50 \mathrm{mM}$ phosphate buffer $(\mathrm{pH}=6)$ containing $1.67 \mathrm{mg} / \mathrm{ml}$ guaiacol and $0.0005 \%$ hydrogen peroxide. The change in absorbance at $490 \mathrm{~nm}$ was measured. MPO activity was expressed in units $/ \mathrm{mg}$ tissue. One unit of MPO activity = $1 \mathrm{milli}$ moleperoxide degraded per minute at $25^{\circ} \mathrm{C}$ [19].

\section{Estimation of cellular nitrite levels}

The concentration of nitrite was estimated by the method of Lepoivre et al., 1990. To $0.5 \mathrm{ml}$ of cell lysate, $0.1 \mathrm{ml}$ of sulfosalicylic acid was added and vortexed well for $30 \mathrm{~min}$. The samples were then centrifuged at $5000 \mathrm{rpm}$ for $15 \mathrm{~min}$. The protein-free supernatant was used for the estimation of nitrite levels. To $200 \mu \mathrm{l}$ of the supernatant, $30 \mu \mathrm{l}$ of $10 \%$ $\mathrm{NaOH}$ was added, followed by $300 \mu \mathrm{l}$ of Tris-HCl buffer and mixed well. To this, $530 \mu \mathrm{l}$ of Griess reagent was added and incubated in the dark for 10-15 min, and the absorbance was read at $540 \mathrm{~nm}$ against a Griess reagent blank. Sodium nitrite solution was used as the standard [19,22]. 


\section{RESULTS}

\section{Cell viability assay}

The cell viability curve of RAW 264.7 cells treated with varying concentrations of ESBE of $K$. attenuata is displayed in Fig. 1. The extract was found to be nontoxic with an $\mathrm{IC}_{50}$ value $>250 \mu \mathrm{g} / \mathrm{ml}$.

\section{In vivo pharmacological activity}

Carrageenan-induced paw edema in rats

Carrageenan-induced paw edema is a model for evaluating acute antiinflammatory activity. The subplantar injection of carrageenan in control rats $(\mathrm{n}=6)$ induced a time-dependent increase in paw volume, which peaked at $3^{\text {rd }} \mathrm{h}(1.25 \pm 0.02)$. Treatment with ESBE (250 and $500 \mathrm{mg} / \mathrm{kg} \mathrm{p.o)} 1 \mathrm{~h}$ before carrageenan administration resulted in a dose-dependent reduction in paw edema providing the maximum effect $(60.83 \%)$ at the dose of $500 \mathrm{mg} / \mathrm{kg}$. Indomethacin $(10 \mathrm{mg} / \mathrm{kg})$ has also suppressed carrageenan-induced increase in paw volume at the $4^{\text {th }} \mathrm{h}$ with an inhibition percentage of $70.63 \%$.

\section{Cotton pellet granuloma method}

Implantation of cotton pellets resulted in the formation of granulomatous tissue in all experimental groups (Fig. 3). Fig. 4 shows the average dry weight of the cotton pellets removed from rats, which indicate a reduction in granuloma tissue formation due to the treatment with both standard drug dexamethasone and the ESBE of $K$. attenuata. The percentage inhibition of granuloma tissue formation by test extract ( $500 \mathrm{mg} / \mathrm{kg}$ ) was comparable to that obtained from standard and was found to be $41.28 \%$ and $52.73 \%$, respectively.

\section{In vitro anti-inflammatory studies}

In vitro anti-inflammatory activity in cell lines

COX inhibition assay

COX-1 and COX-2 are an enzyme that is responsible for the formation of prostaglandins during acute inflammation. The percentage COX inhibition by diclofenac sodium (standard) and different concentrations of ESBE is presented in Fig. 5. ESBE $(100 \mu \mathrm{g} / \mathrm{ml})$ and diclofenac sodium (standard, $10 \mu \mathrm{g} / \mathrm{ml}$ ) showed a percentage inhibition of COX activity by $51.83 \%$ and $61.33 \%$, respectively.

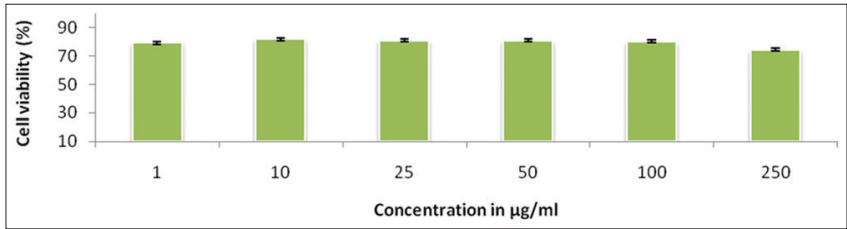

Fig. 1: Cell viability curve of RAW 264.7 cells exposed to varying concentrations of ethanolic stem bark extract. $n=3$; values were expressed in mean \pm standard error of the mean. RAW 264.7 cells were activated with $1 \mu \mathrm{g} / \mathrm{ml}$ of LPS

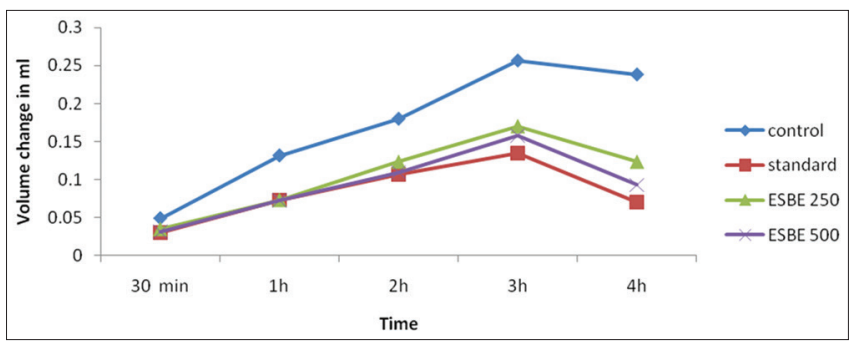

Fig. 2: Comparison of paw volume of groups at different time intervals $n=6$; values were expressed in mean \pm standard error of the mean; indomethacin $10 \mathrm{mg} / \mathrm{kg}$, ethanolic stem bark extract $250 \mathrm{mg} / \mathrm{kg}$, and $500 \mathrm{mg} / \mathrm{kg}$ were compared to control; one-way ANOVA followed by Dunnett's t-test. $p<0.001$ compared to control at $4^{\text {th }} h$

\section{LOX inhibitory assay}

5-Lipoxygenase is an enzyme that is involved in the production of leukotrienes (an inflammatory mediator). Inhibition of 5-lipoxygenase by ESBE of $K$. attenuata was observed to be not significant as compared to that of standard.

\section{Estimation of MPO enzyme activity}

Anti-inflammatory effect of extract was elucidated by the reduction in MPO enzyme activity which catalyzes the formation of free radicals secreted during inflammation. The decrease in MPO activity after treatment with diclofenac (standard) and different concentrations of extract is presented in Fig. 6. ESBE $(100 \mu \mathrm{g} / \mathrm{ml})$ showed an effect on par with that of standard, diclofenac.

\section{Estimation of cellular nitrite level}

The cellular nitrite level an indicator of nitric oxide free radical produced during inflammation was found to decrease with an increasing concentration of ESBE. The values obtained (Fig. 7) showed a comparable effect with that of standard (sodium nitrite).

\section{DISCUSSION}

Medicinal plants are a rich source of natural compounds that offer significant therapeutic potential for treating various disease conditions. Many of them are used in folk medicine with or without a proper scientific basis. The ethnopharmacological use of stem bark of plant $K$. attenuata in inflammatory conditions has been described by Ravikumar and Ved (2000). To establish a scientific basis for the antiinflammatory action of ESBE of $K$. attenuata, various in vivo and in vitro screening techniques were applied in this study.

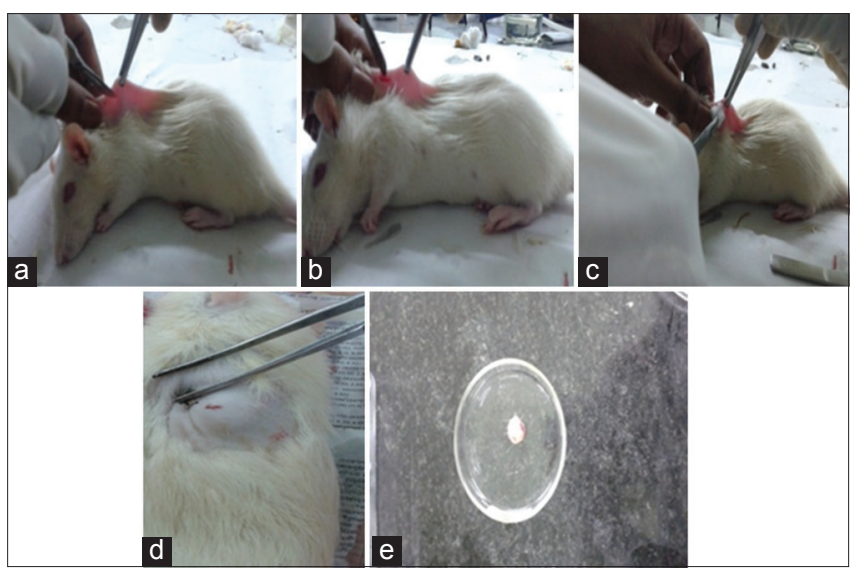

Fig. 3: Photographs (a-d) showing cotton pellet-induced granuloma in the axilla region of rats and (e) cotton pellet removed after animal sacrifice

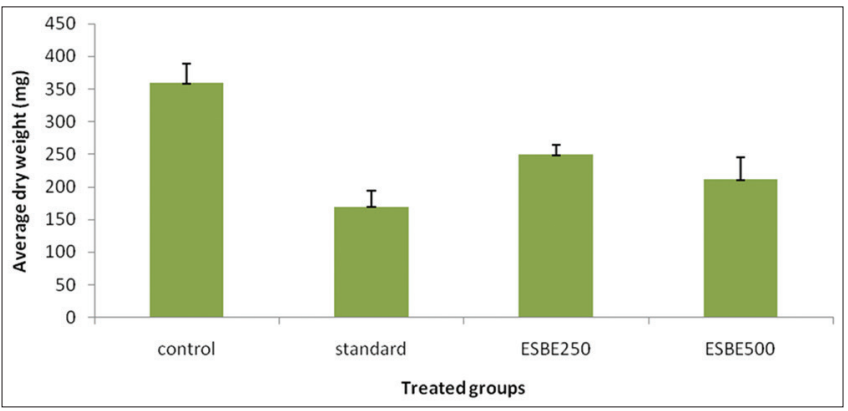

Fig. 4: Comparison of average dry weight of cotton pellets removed from rats. $n=6$, Values were expressed in mean \pm standard error of the mean. Ethanolic stem bark extract (ESBE) $250 \mathrm{mg} / \mathrm{kg}$ and $500 \mathrm{mg} / \mathrm{kg}$ was compared to control; oneway ANOVA followed by Dunnett's t-test. ESBE treated groups; $\mathrm{p}<0.01, \mathrm{p}<0.001$ compared to control 


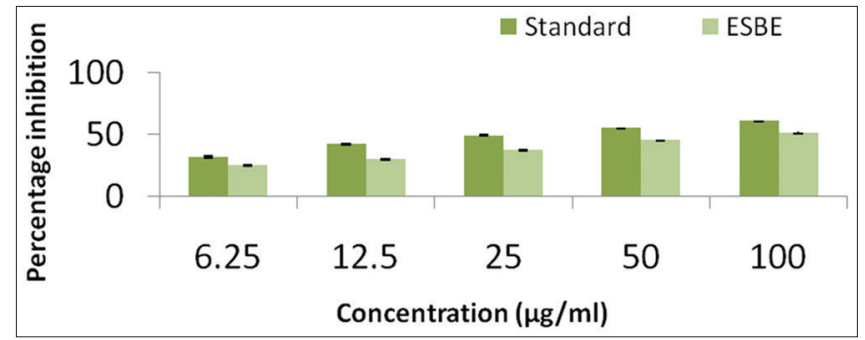

Fig. 5: Comparison of percentage inhibition of cyclooxygenase activity. $n=3$, values were expressed in mean \pm standard error of the mean. $\mathbf{p}<0.0001$, Optical density of standard and ethanolic stem bark extract $(100 \mu \mathrm{g} / \mathrm{ml})$ was compared with control (oneway ANOVA followed by Dunnett's t-test)

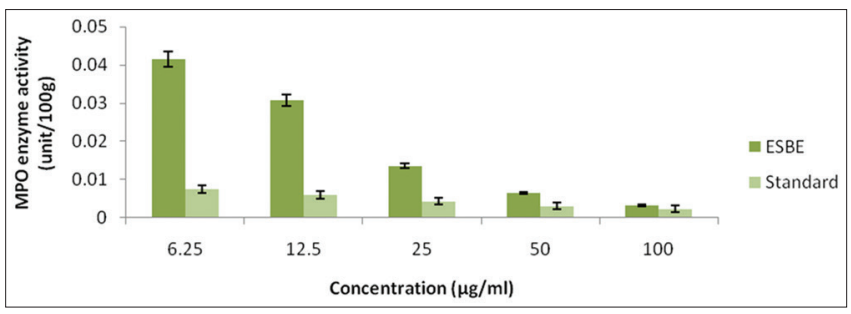

Fig. 6: Comparison of decrease in myeloperoxidase enzyme activity. $n=3$, values were expressed in mean \pm standard error of the mean. $\mathbf{p}<\mathbf{0 . 0 0 0 1}$, optical density of standard and ethanolic stem bark extract $(100 \mu \mathrm{g} / \mathrm{ml})$ were compared with control (oneway ANOVA followed by Dunnett's t-test)

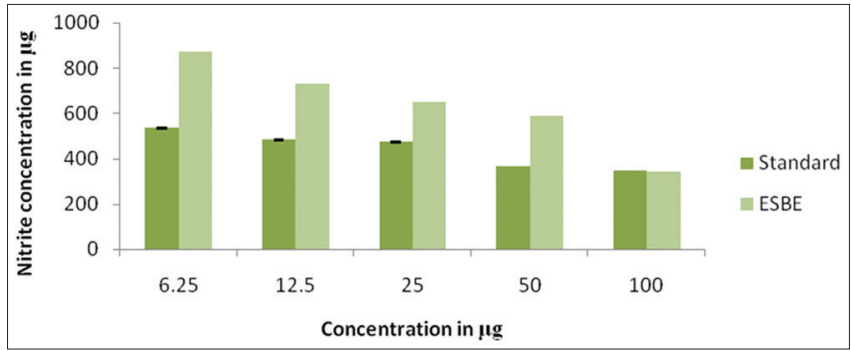

Fig. 7: Comparison of cellular nitrite level. $n=3$, values were expressed in mean \pm standard error of the mean. $p<0.0001$, optical density of standard and ethanolic stem bark extract $(100 \mu \mathrm{g} / \mathrm{ml})$ were compared with control (one-way ANOVA followed by Dunnett's t-test)

Study of acute phase of inflammation was carried out using carrageenaninduced paw edema, astandard in vivomodel thatscreens anti-inflammatory agents which act by inhibiting mediators of acute inflammation [17]. Carrageenan-induced rat paw edema is a biphasic response in which the early phase involves mast cell degranulation, histamine, and serotonin release $(1-2 \mathrm{~h})$ and further bradykinin release and pain followed by prostaglandin production in the later phase $(3-4 \mathrm{~h})[23,24]$. Since the edema produced is known to be sensitive to COX, the non-steroidal antiinflammatory agents which are COX inhibitors of prostaglandin synthesis were used as standards for this assessment [25]. In this study, oral administration of ESBE showed antiedemal activity at both doses tested. Ethanolic extract $(500 \mathrm{mg} / \mathrm{kg}$ ) was more effective than its lower dose and showed a significant $(\mathrm{p}<0.0001)$ percentage inhibition of $60.83 \%$ with an added benefit of reduced toxicity compared to indomethacin (standard), which provided $70.63 \%$ but caused adverse effects. Both indomethacin and ethanolic extract showed inhibition of increase in paw volume at the $4^{\text {th }} \mathrm{h}$ indicating their similar mechanism of action.

The cotton pellet-induced granuloma was used to determine the transudative and proliferative components of subacute inflammation.
The weight of dry cotton pellets correlates with the amount of granulomatous tissue formed. Dexamethasone was taken as reference standard as steroidal drugs have shown more inhibition on the granuloma formation compared to NSAIDs [26]. In this study, the administration of $K$. attenuata extract $(250 \mathrm{mg} / \mathrm{kg}$ and $500 \mathrm{mg} / \mathrm{kg}$, p.o.) inhibited the granuloma formation in a dosedependent manner indicating an effective suppression of proliferative phase of inflammation by the extract.

According to ISO 10993, biocompatibility of any agent should be first evaluated using in vitro cytotoxicity test, and further tests in laboratory animals (in vivo) could be carried out only if proved to be nontoxic [27]. In cell viability testing using MTT assay method, ESBE showed an IC $>250 \mu \mathrm{g} / \mathrm{ml}$ indicating a low cell toxicity.

In vitro screening techniques are a faster, simpler, and more predictive alternative to in vivo techniques that can be used to elucidate the possible mechanisms involved in the anti-inflammatory action expressed by the extract. RAW 264.7 a murine macrophage cell line was employed for screening anti-inflammatory action in vitro [15].

In vitro anti-inflammatory activity of ESBE was determined using cell lines, which confirmed the results obtained from in vivo experiments. Anti-inflammatory assay techniques such as COX inhibitory assay, LOX inhibitory assay, estimation of MPO activity, and estimation of cellular nitrite level were carried out on cell lysate to determine the possible mechanisms behind the action shown by extract.

COX and LOX are two enzymes involved in arachidonic pathway that triggers inflammation. The exact mechanism of inhibition of COX and LOX enzymes by natural products is not elucidated. Since both pathways include free radical reactions, due to their radical scavenging activity or reducing properties, many plant natural products can interfere with reactions catalyzed by COX and LOX, neutralize radical intermediates and thus terminates the reaction. Otherwise, they can reduce $\mathrm{Fe}^{3+}$ ion, which is a part of active site of both enzymes and is necessary for initiation reaction. The differences in COX and LOX inhibitions would be due to the differences in reaction mechanism and active site three-dimensional structures [28]. K. attenuata contains flavonoids and saponins for which antioxidant activity has been already established [29]. The ethanolic extract showed significant COX inhibition activity in LPS-stimulated RAW 264.7 macrophage cells with a percentage inhibition of $51.09 \%$, respectively.

Accumulation of neutrophils and macrophages at the site of inflammation is a prominent feature in inflammatory processes. Therefore, their quantification in inflamed tissue using MPO enzyme estimation method can be useful for predicting the intensity of inflammation. MPO enzyme catalyzes the formation of reactive oxygen species and is secreted during inflammation [30]. In this study, both diclofenac and $100 \mu \mathrm{g}$ ESBE of $K$. attenuata exhibited a decrease in the MPO activity to similar levels ( 0.0023 and 0.0032 units $/ \mathrm{mg}$, respectively) and suggested that inhibition of leukocyte infiltration can also be a mechanism by which the extract exhibits its anti-inflammatory properties.

In the next method, the cellular nitrite level an indicator of nitric oxide free radical produced during inflammation was found to decrease with an increase in the concentration of ethanolic extract [15]. $100 \mu \mathrm{g} / \mathrm{ml}$ of ethanolic extract was comparable with that of the standard $(347.49 \mu \mathrm{g}$ and $339.94 \mu \mathrm{g}$, respectively).

The in vivo and in vitro methods have provided much scientific evidence for the traditional use of stem bark of $K$. attenuata for the treatment of inflammatory conditions. The anti-inflammatory action exhibited by the extract was due to inhibition of leukocyte migration and NO pathway and partially by inhibition of mediators such as prostaglandins. The anti-inflammatory action of the ESBE can be attributed to the presence of flavonoids and polyphenolic compounds identified in the preliminary phytochemical analysis of extract. 
This study showed that stem bark extract of $K$. attenuata possesses promising anti-inflammatory activity in both in vitro and in vivo conditions. Further detailed study is recommended to determine the active constituents present in the extract so that researches on other pharmacological activities of stem bark of $K$. attenuata can be conducted.

\section{ACKNOWLEDGMENT}

The author is grateful to Mr. Suku J, Associate professor (Pharmacology), College of Pharmaceutical sciences, Trivandrum, for his guidance during the study. I acknowledge the guidance and encouragement from Mr. Rajasekharan, Department of Pharmacology, Jamia Salafiya Pharmacy College and Mr. Sreekanth G.B, Scientist-FRM, ICAR Goa for this study.

\section{AUTHORS' CONTRIBUTIONS}

Conception and design, acquisition, analysis and interpretation of data, and writing of the manuscript were carried out by the corresponding author.

\section{DECLARATION OF CONFLICTS OF INTEREST}

The author declares no conflicts of interest in preparing this article.

\section{REFERENCES}

1. Ferrero-Miliani L, Nielsen OH, Andersen PS, Girardin SE. Chronic inflammation: Importance of NOD2 and NALP3 in interleukin-1beta generation. Clin Exp Immunol 2007;147:227-35.

2. Feghali CA, Wright TM. Cytokines in acute and chronic inflammation. Front Biosci 1997;2:d12-26.

3. Walter JB, Talbot IC. General Pathology. $7^{\text {th }}$ ed. London: Churchill Livingstone; 2009

4. Khanna HD, Karki K, Pande D, Negi R, Khanna RS. Inflammation, free radical damage, oxidative stress and cancer. Int J Inflamm Cancer Integr Ther 2014;1:109.

5. Gui T, Shimokado A, Sun Y, Akasaka T, Muragaki Y. Diverse roles of macrophages in atherosclerosis: From inflammatory biology to biomarker discovery. Mediators Inflamm 2012;2012:693083.

6. Osadebe PO, Okoye FB. Anti-inflammatory effects of crude methanolic extract and fractions of Alchornea cordifolia leaves. J Ethnopharmacol 2003;89:19-24.

7. McGettigan P, Henry D. Use of non-steroidal anti-inflammatory drugs that elevate cardiovascular risk: An examination of sales and essential medicines lists in low middle and high-income countries. PLoS Med 2013;10:e1001388.

8. Krishnaveni J, Mangai AS, Jency MI. In vitro anti-inflammatory activity of blue-green algae Geitlerinema splendidum collected from Western Ghats, South India. Asian J Pharm Clin Res 2018;11:407-9.

9. Available from: http://www.indiabiodiversityorg/biodiv/species/show/13965.

10. Ravikumar K, Ved DK. One Hundred Red Listed Medicinal Plants of Conservation Concern in Southern India. Bangalore: Foundation for Revitalisation of Local Health Traditions; 2000. p. 219-22.

11. Joshi BS, Ravindranath KR, Viswanathan N. Structure and stereochemistry of attenuol, a new lignan from Knema attenuata (Wall.) Warb. Experientia 1978;34:422.
12. Korkina LG. Phenylpropanoids as naturally occurring antioxidants: From plant defense to human health. Cell Mol Biol (Noisy-le-grand) 2007;53:15-25.

13. Pinto MM, Kijjoa A. Chemical study of Knema species from Thailand. Quim Nova 1990;13:243-4.

14. Khadabadi SS, Deore BS. Pharmacognosy and Phytochemistry: Experimental Phytopharmacognosy a Comprehensive Guide. $2^{\text {nd }}$ ed. Mumbai: Nirali Prakasan; 2014.

15. Joo T, Sowndhararajan K, Hong S, Lee J, Park SY, Kim S, et al. Inhibition of nitric oxide production in LPS-stimulated RAW 264.7 cells by stem bark of Ulmus pumila L. Saudi J Biol Sci 2014;21:427-35.

16. Freshney RI. Culture of Animal Cells: A Manual of Basic Techniques. $5^{\text {th }}$ ed. John Wiley and Sons, Inc.; 2005. p. 321.

17. Winter CA, Risley EA, Nuss GW. Carrageenin-induced edema in hind Paw of the rat as an assay for antiiflammatory drugs. Proc Soc Exp Biol Med 1962;111:544-7.

18. Winter CA, Porter CC. Effect of alterations in side chain upon antiinflammatory and liver glycogen activities of hydrocortisone esters. J Am Pharm Assoc Am Pharm Assoc 1957;46:515-9.

19. Kurian NK, Nair HP, Bhat SG. Evaluation of anti-inflammatory property of melanin from marine Bacillus Spp. BTCZ31. Asian J Pharm Clin Res 2015;8:251-5.

20. Walker MC, Gierse JK. In vitro assays for cyclooxygenase activity and inhibitor characterization. Methods Mol Biol 2010;644:131-44.

21. Axelrod B, Cheesebrough TM, Laakso S. Lipoxygenase from soyabean. Methods Enzymol 1981;71:441-5.

22. Lepoivre M, Chenais B, Yapo A, Lemaire G, Thelander L, Tenu JP, et al. Alterations of ribonucleotide reductase activity following induction of the nitrite-generating pathway in adenocarcinoma cells. J Biol Chem 1990;265:14143-9.

23. Necas J, Bartosikova L. Carrageenan: A review. Vet Med 2013;58:187-205.

24. Hendra P, Fenty, Andreani PR, Pangestuti B, Julianus J. Evaluation of antihyperlipidemic, anti-inflammatoryand analgesic activities of Eurycoma longifolia in animal models. Int J Pharm Pharm Sci 2017;9:166-9.

25. Chaithanya KK, Gopalakrishnan VK, Hagos Z, Rao GD. Mesuaferrin A-bioactive flavanoid isolated from the bark of Mesua ferrea L., against phospholipase $\mathrm{A}_{2}$, Cyclooxygenase and lipooxygenase: An in vitro, in vivo and in silico approach. Int J Pharm Pharm Sci 2017;10:102-6.

26. Swingle KF, Shideman FE. Phases of the inflammatory response to subcutaneous implantation of a cotton pellet and their modification by certain anti-inflammatory agents. J Pharmacol Exp Ther 1972;183:226-34.

27. Rogero S. Lugao A. Ichikawa IT, Cruz AS. In vitro cytotoxicity test: A comparative study between two methodologies. Mater Res 2003:3:317-20.

28. Neda MD Simin N, Svirčev E, Orčić D. Lipid peroxidation. The Effect of Plant Secondary Metabolites on Lipid Peroxidation and Eicosonoid Pathway. Ch. 9. USA: Intech.; 2012. p. 204-6.

29. Vinayachandra, Chandrashekhar KR. Phenolic contents of Knema attenuata fruits and their bioactive potentials. J Herbs Spices Med Plants 2014;20:183-95

30. Ashok P, Koti BC, Thippeswamy AH, Tikare VP, Dabadi P, Viswanathaswamy $\mathrm{AH}$, et al. Evaluation of antiinflammatory activity of Centratherum anthelminticum (L) kuntze seed. Indian J Pharm Sci 2010;72:697-703. 